\title{
FACS for Fungi: revealing population heterogeneity among fungal pathogens via flow cytometry
}

\author{
Elizabeth R. Ballou*, Alistair JP Brown \\ From 1st Annual Meeting of the Scottish Society of Cytomics (SCC) 2014. "Translational Cytometry from \\ Bench to Bedside" \\ Aberdeen, UK. 25 September 2014
}

\begin{abstract}
Although we often consider pathogens as presenting a single face to the immune system, it is clear that this "golf ball" model of pathogen-host interaction limits our understanding of population dynamics in the host. For example, others have shown that population heterogeneity in surface antigen presentation by Trypanosoma brucei and heterogeneity in the expression of pathogenicity factors by Vibrio harveyi and the human fungal pathogen Candida albicans are required for full virulence of these organisms $[1,2,3]$. This is perhaps counter-intuitive, given a working model in which virulence factor expression is correlated to degree of pathogenicity of a given organism. In this work, we discuss the application of flow cytometry techniques to the analysis of fungal pathogens. Specifically, we examine the impact of environmental fluctuations in nutrient availability on the presentation of cell wall components on the surface of fungal cells and use these features as markers for population heterogeneity. We demonstrate that population heterogeneity can be modulated by environmental conditions such as carbon source availability. We show that heterogeneity is rapidly lost when cells grown in a mixed nutrient environment representative of in vivo conditions are transitioned to the single nutrient conditions more typical of in vitro laboratory culture, and is slow to re-emerge when cells are transitioned back. Moreover, we show that heterogeneity in the presentation of pathogenassociated molecular patterns is similarly modulated by environmental conditions. Together, our observations underscore the potential for population-based analyses in investigating host-pathogen dynamics.
\end{abstract}

Published: 16 April 2015

\footnotetext{
* Correspondence: e.ballou@abdn.ac.uk

Aberdeen Fungal Group, School of Medical Sciences, University of Aberdeen, Institute of Medical Sciences, Foresterhill, AB25 2ZD, UK
}

\section{References}

1. Dubois ME, Demick KP, Mansfield JM: Trypanosomes Expressing a Mosaic Variant Surface Glycoprotein Coat Escape Early Detection by the Immune System. Infection and Immunity 2005, 73(5):2690-2697.

2. Anetzberger $C$, Pirch $T$, Jung $K$ : Heterogeneity in quorum sensingregulated bioluminescence of Vibrio harveyi. Molecular Microbiology 2009, 73(2):267-277.

3. Pierce JV, Kumamoto CA: Variation in Candida albicans EFG1 Expression Enables Host-Dependent Changes in Colonizing Fungal Populations. mBio 2012, 3:4e00117-12.

doi:10.1186/1476-9255-12-S1-O3

Cite this article as: Ballou and Brown: FACS for Fungi: revealing population heterogeneity among fungal pathogens via flow cytometry. Journal of Inflammation 2015 12(Suppl 1):O3.
Submit your next manuscript to BioMed Central and take full advantage of:

- Convenient online submission

- Thorough peer review

- No space constraints or color figure charges

- Immediate publication on acceptance

- Inclusion in PubMed, CAS, Scopus and Google Scholar

- Research which is freely available for redistribution
() Biomed Central
C Biomed Central

(c) 2015 Ballou and Brown; licensee BioMed Central Ltd. This is an Open Access article distributed under the terms of the Creative Commons Attribution License (http://creativecommons.org/licenses/by/4.0), which permits unrestricted use, distribution, and reproduction in any medium, provided the original work is properly cited. The Creative Commons Public Domain Dedication waiver (http://creativecommons.org/publicdomain/zero/1.0/) applies to the data made available in this article, unless otherwise stated. 